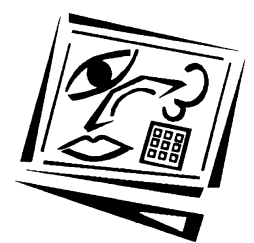

\title{
Using a wiki-based collaborative process writing pedagogy to facilitate collaborative writing among Chinese primary school students
}

\author{
Xuanxi Li, Samuel Kai Wah Chu, Wing Wah Ki and Matsuko Woo \\ The University of Hong Kong
}

\begin{abstract}
This case study explored collaborative writing in Chinese among 59 primary four Chinese students using a Wiki-based Collaborative Process Writing Pedagogy (WCPWP) in Shenzhen, China. It aimed mainly to design and orchestrate a WCPWP in order to facilitate students' Chinese writing. It investigated students' collaborative writing process and their performance on a wiki, and explored the perceptions and attitudes of the teacher and her students towards WCPWP. A wiki-based writing environment named Joyous Writing Club (JWC) was designed and developed using MediaWiki software. Data was collected from questionnaires, online wiki documents, interviews, and observations. The results illustrated students' collaborative writing process and their products on the wiki. Besides, the results showed that students perceived WCPWP was beneficial in boosting writing motivation, increasing group interactions, and extending the audience for their writing. This study may help primary educators gain a deeper understanding of the relationships between technology, pedagogy and education. It may also provide practical recommendations for primary school Chinese language teachers in the integration of Web 2.0 tools (wikis, Google Docs) as well as the use of effective pedagogical strategies in the teaching of Chinese writing.
\end{abstract}

\section{Introduction}

Chinese writing has been described as the most difficult aspect in Chinese language learning for Chinese primary school students (Ma, 2009; Sun, 2008). Students used to complain that Chinese writing is difficult and that they dislike writing (Ma, 2009; Sun, 2008). Huang (2008) indicated that some primary students' writing lacks involvement and is flat and lifeless. Besides, students' writing tends to be mechanical with little sense of the writer's thoughts and feelings (Cui, 2007; Xia, 2009).

In most Chinese primary schools, the method of teaching writing is still traditional, teacher-centred (Sun, 2008) and product-oriented $(\mathrm{Gu}, 2004)$. Teachers usually do not emphasise students' writing processes, but want students to create acceptable products (Gu, 2004). Typically, teachers provide guidance and model essays guided by the textbook and other teaching materials. Students practise writing individually, and then teachers assess and comment on students' writing (Sun, 2008). This approach has been criticised as one of the reasons why some students have low writing ability (Liu, 2009; Xiong, 1995).

In the context of deepening reforms in the Chinese language examination system, the value of writing has been attracting more and more attention ( $\mathrm{Zhu}, 2010)$. During the 
past decade, research on innovative approaches to teaching Chinese writing has flourished (Huang, 2008; Wang, 2004; Wang, 2008; Wu, 2009; Xiong, 1995). Since 2003, the New Standard of Chinese Curriculum has emphasised group interaction in Chinese language learning (New Criteria of Chinese Curriculum, 2003). Recently, researchers and educators have begun to focus on the benefits of collaborative learning in the Chinese writing context (Wu, 2009; Xia, 2009). Reeves (2002) indicated that collaborative learning in writing implies a balancing of authority between students and teachers, since students can participate in their own learning through peer editing and group writing. Collaborative writing provides a way to transcend writers' individual self-centred interest, it also nurtures writers' self-esteem, because their opinions are considered and respected.

Furthermore, Lam (2007) integrated the process writing approach with collaborative learning, which seems effective in motivating students to voice out their thoughts and interact with one another in the process of English writing, and also appears to be able to help students improve their writing skills through being engaged in the developmental process of writing. According to Tobin (2001), the process pedagogy of writing focuses on writing as a process rather than as a product. The process writing approach emphasises the importance of the different stages in composing, by offering students procedures that help them in choosing topics, gathering information, organising their thoughts, composing, and revising (Gage, 1986).

In the area of collaborative learning in Chinese writing in China, however, there has been much less research on how collaborative process writing activities are conducted in classrooms and their effects on students' Chinese writing process and performance. Moreover, little is known about students' and teachers' attitudes and perceptions towards collaborative writing (Xie, 2006). This study is intended to address these gaps.

\section{Literature review}

Some scholars have pointed out that unless collaborative activities are carefully orchestrated by the teacher, students may not take group work seriously, socialising instead of working, allocating most of the work to one member, completing the activity superficially, and generally not engaging fully in a collaborative process (Clark, 2003; Spigelman, 1998). The use of an educational technology such as wikis may help address these limitations and provide a useful platform for facilitating collaborative learning. This is due to an important feature of wikis, as Lamb and Johnson (2007) emphasised, the history function. This can record automatically the history of revisions, and help students and teachers trace and reflect on the progress of the collaborative learning and the contributions by each participant.

According to Ciesielka (2008), a wiki is an innovative means of creating, editing, and disseminating information in an online environment, which can be authored collectively. Some distinctive features of wikis have been identified as being particularly powerful in supporting collaborative learning, compared to other Web 2.0 technologies. Lamb (2004) pointed out two important features of a wiki. One is its open editing function, which allows users to add anything to a wiki at anytime. It is important to emphasise here that participants can both add and delete each other's content in the wiki page (Pifarré \& Staarman, 2011). The second is its discussion forum function, which helps writers share their ideas for enhancing the page and provide explanations of their additions and changes. 
Bower (2008) systematically reviewed and summarised the affordances of wikis (media affordances, spatial affordances, temporal affordances, navigational affordances, emphasis affordances, synthesis affordances, and access control affordances) which can be utilised appropriately for collaborative learning tasks. Woo, Chu, Ho and Li (2011) further demonstrated that the wiki affordances matched the requirements of collaborative writing tasks. Taken together, these wiki affordances and functions (e.g. history function, discussion forum function) make it helpful in facilitating collaborative writing activities.

The rapid development of wikis and their technology affordances has resulted in their widespread use as platforms to support collaborative writing (Mak \& Coniam, 2008; Wong, Chen, Chai, Chin \& Gao, 2011; Woo, Chu, Ho \& Li, 2009, 2011). In recent years, real time collaborative editing (RTCE) wiki systems such as PBworks.com, Wikispaces.com, Wetpaint.com and Wikia.com have been widely used by educators and researchers to support English writing (PBworks, 2010; Wetpaint, 2010; Wikia, 2010; Wikispaces, 2010). There have been wiki projects such as the National Writing Project (NWP), which includes 200 university-affiliated sites across the United States built to improve the teaching and learning of writing in English.

Few researchers have investigated collaborative learning in Chinese writing, and even fewer have examined the potential of a wiki environment for supporting collaborative Chinese writing in China (Xie, 2006). To address these gaps, this study therefore used a wiki to support collaborative process writing activities among upper primary school Chinese students. To this end, this study designed and orchestrated a Wiki-based Collaborative Process Writing Pedagogy (WCPWP) in order to improve students' writing ability effectively.

\section{Conceptual model of wiki-based collaborative process writing pedagogy}

In order to carry out the collaborative writing activity, a Wiki-based Collaborative Process Writing Pedagogy (WCPWP) was designed for this study. The theoretical model of WCPWP is based on social constructivist theory and the social view of writing process theory. This study integrates features of social constructivist theory (Vygotsky, 1978) and the social view of writing process theory (Faigley, 1986; Tompkins, 2008), and puts forward a clear integrated conceptual model of the pedagogy. The model is illustrated in Figure 1.

This model was negotiated between the researcher and the Chinese language teacher of the class, as the basis for the design of the wiki platform, the teaching and learning plan, and class organisation. The Chinese language teacher allocated students to different groups, with each group comprising four students with mixed writing abilities: two students with higher Chinese writing ability, and two students with lower writing ability. The levels of students' writing abilities were classified by the Chinese language teacher, based on the records of students' composition scores.

This model elucidates that the use of a wiki-based writing environment was supported by social constructivist theory, and the wiki-based writing activities would occur in a collaborative context (see top part of Figure 1). According to Witts (2011), a wiki allows students to view each other's ideas, change other people's comments, and build upon their knowledge by interacting with the other students. The use of a wiki that requires social interaction leads itself towards the social constructivist theory which states that knowledge is the result of social interaction. In this study, students in each group 
worked together to write one composition on a single wiki page. Students in different groups could view and comment on each other' writing. The teacher could be also involved in this process to provide each group with guidance and help facilitate their writing (see top part of Figure 1). The collaborative process within groups has been shown to support and promote multiple perspectives through dialogue and discourse. Additionally, electronic communications between and among groups have been found to support an effective constructivist instructional strategy that fosters social negotiation (Almala, 2006).

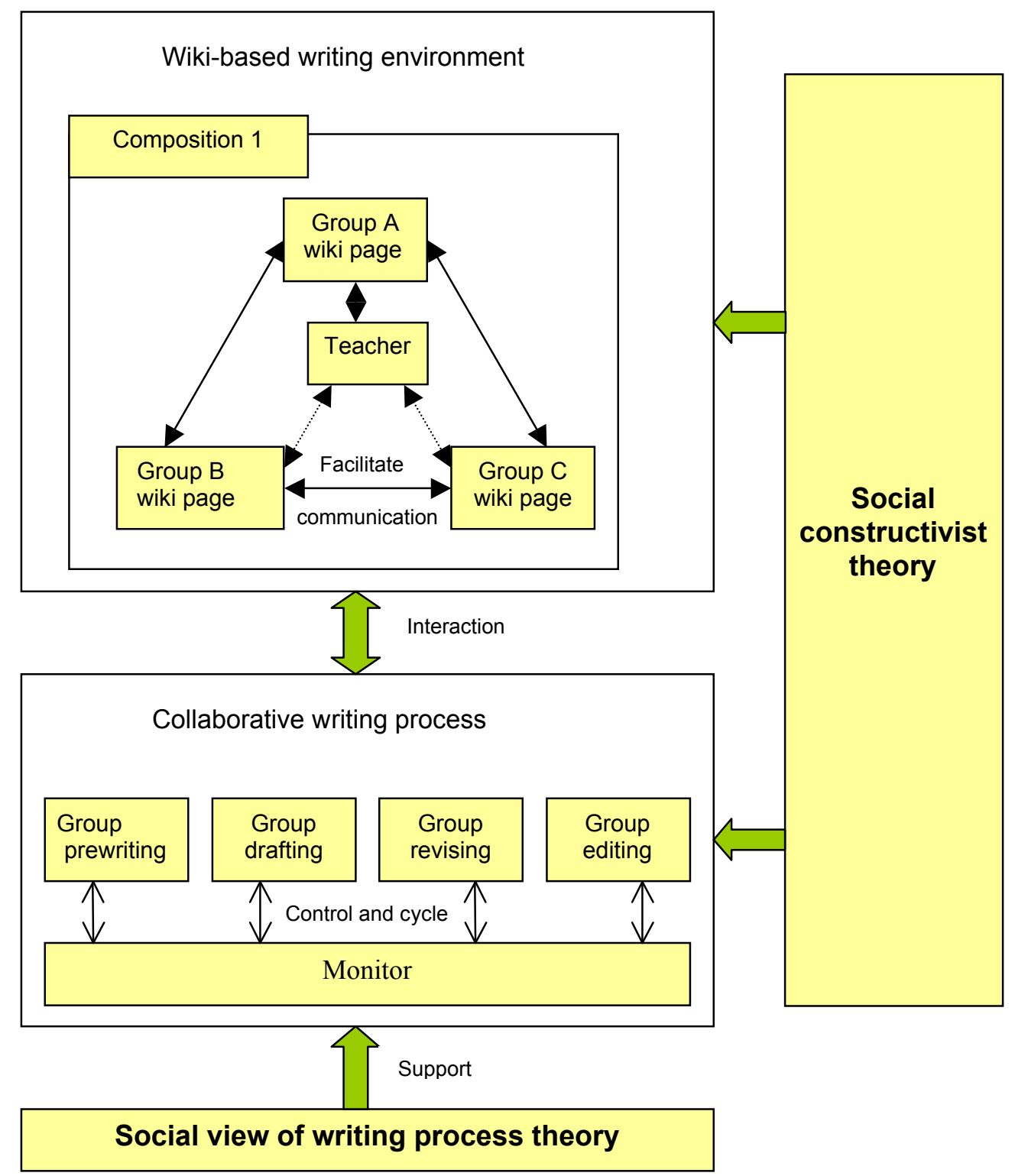

Figure 1: Conceptual model of wiki-based collaborative process writing pedagogy 
The design of the collaborative writing task was supported by both the social view of writing process theory and the social constructivist theory (see bottom part of Figure 1). Social constructivist theory emphasises the critical importance of culture and the social context of cognitive development. It proposes that individuals perceive the world and shape discourse according to the shared beliefs and perceptions of the community or communities to which they belong (Vygotsky, 1978). According to Hewett (2009), social constructivist approaches to composition are often associated with collaborative learning in writing classes, it suggests that knowledge is constructed among social groups and that students need to be acculturated into the academic community. It also argues that knowledge is not certain and that the group or social voice is privileged over the individual's voice.

The social theory of writing assumes that all writing is a conversation between members of a discourse community. Reading and responding to texts within a discourse is central to this view. The social perspective upon writing processes is very prominent in research on the collaborative pedagogy of writing (Faigley, 1986). According to Tompkins (2008), the writing process describes what students think and do as they write, supporting the collaborative writing activity. It consists of nonlinear and recurrent cyclic series of five stages: prewriting, drafting, revising, editing, and publishing. The labeling of the stages is simply an aid to identifying writing activities (Tompkins, 2008). Based on Tompkins's (2008) definition and description of the writing process, in this study, the collaborative writing task for each group was divided into nonlinear and recurrent cyclic series of four stages: group prewriting, group drafting, revising and editing. The progressing of the four stages was monitored by the group members (see bottom part of Figure 1). Students can be better prepared for independent writing once they have learned to go through these writing stages and have developed their own writing strategies (Tompkins, 2008).

\section{Research questions}

This study involved the use of a WCPWP to improve Chinese students' writing ability. More specifically, the study aimed to address the following research questions:

Q1. How do students learn with WCPWP? What are the difficulties they encounter? Q2. What is the level of performance of the students' writing with WCPWP? Q3. What are the attitudes and perceptions of teacher and students towards WCPWP?

\section{Methodology}

\section{Participants}

The participants were 59 primary four students from a primary school in the city of Shenzhen, China. They participated in this study from 27 April to 30 June 2010. The school was rated medium to high in terms of the quality of campus facilities. Teaching and learning activities were conducted in the students' classroom and in one of their computer labs. The computer lab has 56 Shenzhou-brand computers and is equipped with asymmetric digital subscriber line (ADSL) Internet access. The 56 computers share the ADSL data rates, which can be as high as $4 \mathrm{Mb} / \mathrm{s}$ downstream and up to 512 $\mathrm{kb} / \mathrm{s}$ upstream. The students' classroom is equipped with a multimedia presentation facility from the teacher's computer. The whole class of 59 students, with an average age of ten years, and their Chinese language teacher participated in this study. The 
teacher has taught Chinese language for around ten years since graduating with her Bachelor's degree. She has basic computer skills but was not familiar with a wiki. All students in the class returned signed informed consent forms from themselves and their parents. The teacher and school principal also returned signed informed consent forms. The study was reviewed and approved by the Human Research Ethics Committee of the University of Hong Kong,

\section{Learning design}

To support students' collaborative writing, a constructivist learning environment named Joyous Writing Club (JWC) was designed by the first author using MediaWiki software based on Alessi and Trollip's (2001, p.410) model for software design and development. The project of JWC (http://www.joyouswriting.com/) followed the process of planning, design and development with due attention to the requirements concerning standards, ongoing evaluation and efficient project management, and each of the phases of planning, design, and development comprised a variety of issues and actions.

Registered users could use their user names and passwords to enter JWC. In this study, only student participants and the teacher who were authorised by the web manager (the first author) had editing rights and could edit information on the wiki.

Figure 2 shows the layout of the website. On the left of the writing community page are the Navigation Bar and the Tool Bar, where users can switch between wiki pages by clicking links. The writing community page was divided into two main parts: Teacher's Bulletin Corner and Students' Activity Corner.

On the Teacher's Bulletin Corner, there were links for Writing Guidance, Rating Criteria, and Reward Rules. The writing guidance was developed based on Tompkins's (2008) theory of collaborative writing process (Table 1). For the Rating Criteria (Mo, 2010), the researcher and the Chinese language teacher rated group compositions based on the elementary school high-grade narrative scoring criteria (Appendix C). Since the Chinese language teacher likes to offer a range of rewards to improve students' performance in their normal lessons, following the Chinese teacher's suggestion, extrinsic rewards were used in this study in order to help students to maintain their engagement. Rules included rewarding three groups and one student with small gifts (13 students). The best three groups gained small gifts based on their group scores. The personal gift was for the student in the three best groups who actively participated in writing and revised and wrote the most, based on the historical record on the wiki. As Hidi and Harackiewicz (2000) noted, when learning activities are complex and lengthy, a combination of intrinsically appealing elements and extrinsic rewards may be necessary to help students to sustain their engagement.

On the Students' Corner, there was a list of composition tasks (stages of work) aranged as different forums. Students were distributed into 14 groups. In order to encourage students to write, wiki pages for the students' parents were also prepared. For instance, for the first composition, Writing Topics and Requirements, Group wikipage (e.g. Group D) and Parents' Group wikipage (e.g. Parents' Group D) were linked in a forum. Students in each group need to first read the Writing Topic and Requirements, and then write a composition collaboratively on their wiki page. For example, Group B students wrote their compositions on the wiki page of Group B (Figure 3). 


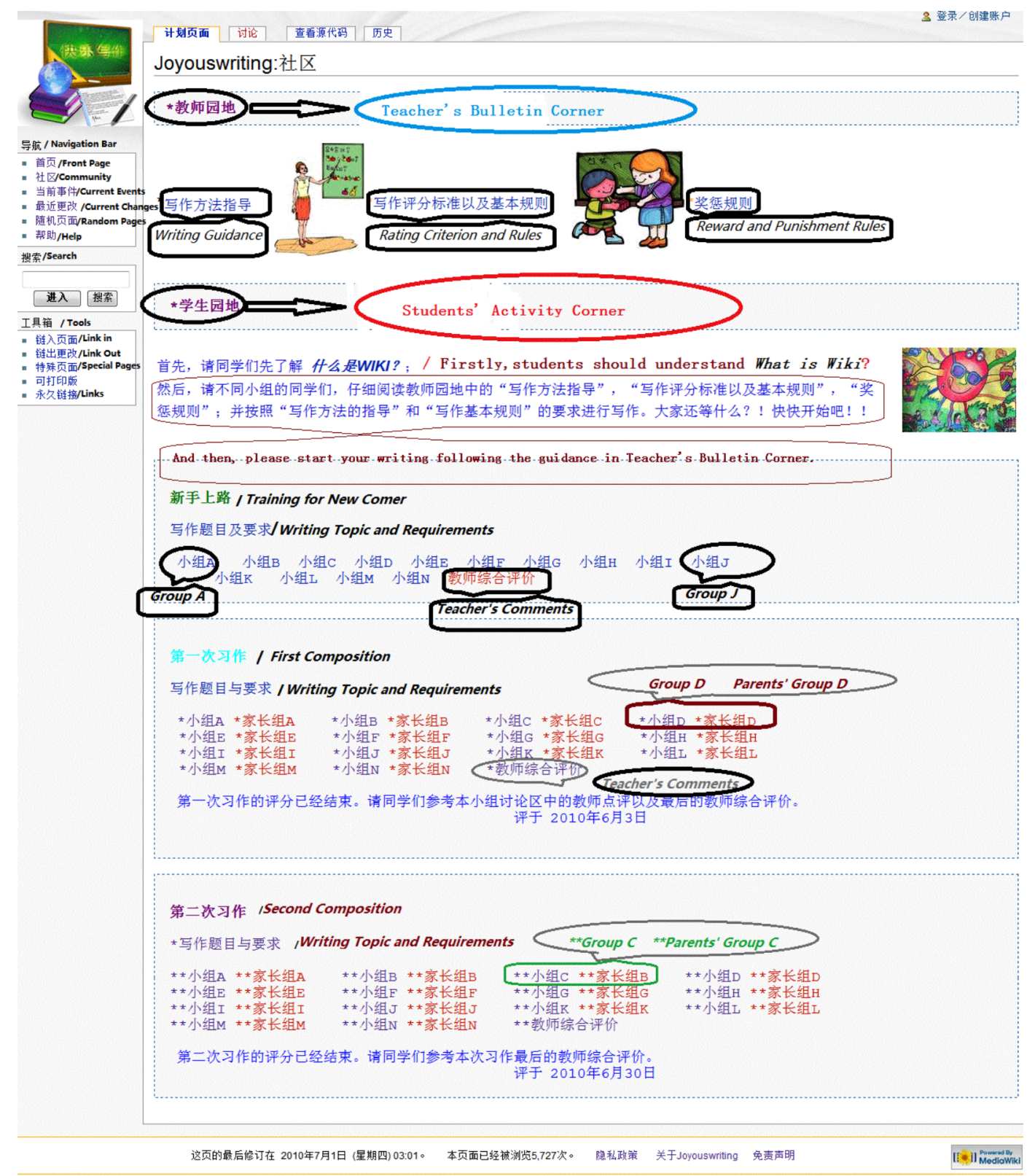

Figure 2: Writing community of Joyous Writing Club

The Chinese teacher and the researcher co-developed the composition topics based on the Primary Four Chinese language syllabuses. The teacher designed the instruction to balance curriculum demands, time constraints, and her personal teaching style. The instruction for one composition was designed as two teaching episodes spanning from one lesson to the other immediately following lesson. In the first lesson, the teacher introduced the writing topic and requirements to students in the classroom, using a multimedia presentation. After discussing the requirements of the composition, the 
teacher asked students to talk about the materials they had collected for the writing, including pictures and related articles, and the materials would be shared among classmates. Afterwards, the teacher guided students to think about how to write their own compositions, and to do some brainstorming with their group mates.

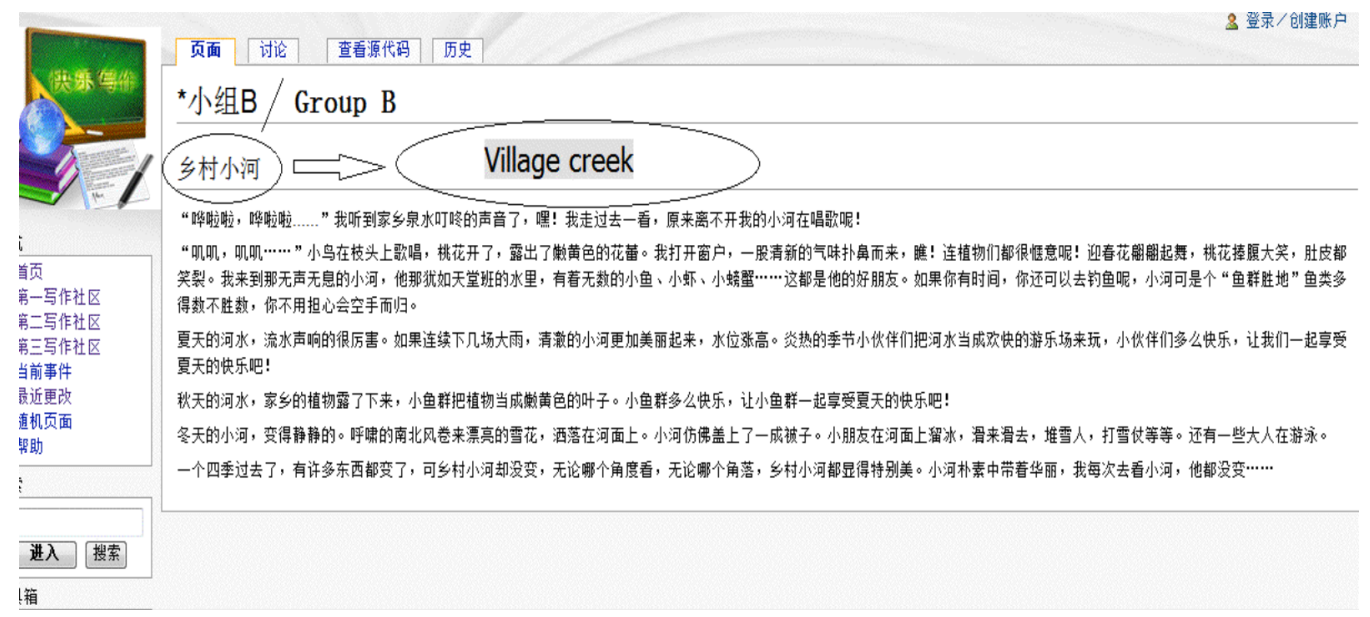

Figure 3: Wiki page by Group B

The second lesson was conducted in a computer lab, with students in the same group sitting adjacent to each other. The teacher guided students in familiarising themselves with the "Joyous Writing Club" system. She selected responsible students to be group leaders to facilitate face to face group discussions and the collaborative writing process. Students were then asked to write compositions collaboratively on JWC, following the four writing stages (Table 1), which could be done in a cyclic, nonlinear and flexible manner.

Unlike a conventional composition with pencil and paper that requires students to submit their compositions within one lesson time, students were able to modify their compositions on the wiki page repeatedly and finish every composition on JWC within one week.

\section{Research design and instruments}

This study collected both quantitative and qualitative data from questionnaires, online wiki documents, observations, and interviews. The study adopted triangulation of data from two or more sources (Bogdan \& Biklen, 2006). Related data from different data collection methods were combined in the study of the same phenomenon in order to take advantage of the strengths of each method while overcoming their flaws (Denzin, 1989).

A questionnaire for the teacher was modified based on the study of Woo et al. (2009). Open ended questions probed the teacher's perceptions and attitudes toward WCPWP (Appendix A - translation by the author). All the questions in the questionnaire were checked by two experts to ensure the content validity and reliability of the questionnaire. 
Table 1: Collaborative writing stages

(based on Tompkins' (2008) description of group writing)

\begin{tabular}{|c|c|l|}
\hline Stage & Name & \multicolumn{1}{|c|}{ Description } \\
\hline 1 & $\begin{array}{c}\text { Group } \\
\text { prewriting }\end{array}$ & $\begin{array}{l}\text { During the prewriting stage, students in each group considered and } \\
\text { discussed the context, purpose, audience, and genre for their writing. They } \\
\text { considered also whether they knew enough about their topic and what their } \\
\text { writing topic was. Students could gather ideas and information by reading } \\
\text { books, searching the Internet, and discussing with their group members. The } \\
\text { group leader made a final decision on their writing, and posted their final } \\
\text { ideas on the wiki page. }\end{array}$ \\
\hline 2 & $\begin{array}{c}\text { Group } \\
\text { drafting }\end{array}$ & $\begin{array}{l}\text { In this stage, students in each group wrote the first draft together on their } \\
\text { wiki page. The students developed their own content, based on their previous } \\
\text { ideas. All the students in the group could organise the structure and express } \\
\text { their ideas and feelings quickly, collaboratively, and with little concern about } \\
\text { character writing, correctness and punctuation. In this stage, their drafts } \\
\text { emphasised the ideas and content of their writing. }\end{array}$ \\
\hline 3 & $\begin{array}{l}\text { Group } \\
\text { revising }\end{array}$ & $\begin{array}{l}\text { Revising is a complex process comprising three activities: re-reading the } \\
\text { rough draft, sharing the rough draft, and revising based on peers' comments } \\
\text { and feedback. Students might choose to change some words, or reorganise a } \\
\text { part completely on the wiki. }\end{array}$ \\
\hline 4 & $\begin{array}{l}\text { Group } \\
\text { editing }\end{array}$ & $\begin{array}{l}\text { Editing is a stage in which the piece of writing is put into its final form. When } \\
\text { editing, students could view the piece in terms of word choice and } \\
\text { correctness of content, sentence structure, spelling errors and punctuation } \\
\text { problems. Students were encouraged to edit their group work again on the } \\
\text { wiki a few days after they finished their composition. The period of waiting } \\
\text { might provide students with a fresh perspective and the enthusiasm } \\
\text { necessary to finish the writing process. At the end, the leader needed to } \\
\text { confirm the completion of their writing. }\end{array}$ \\
\hline
\end{tabular}

A course feedback questionnaire that was modified from previous studies (Hazari, North \& Moreland, 2009; Liang, 1995) was used to explore students' perceptions of the WCPWP. The questionnaire (Table 4) comprised 21 questions using a five-point Likerttype scale, and the questions were intended to measure five subscales: motivation (6 items), interaction (6 items), teacher's role ( 3 items), audience ( 2 items) and technology factors (4 items). Cronbach's alpha reliability value for the overall scale was 0.79 . For the different subscales, motivation had an alpha of 0.87; group interaction alpha was 0.63 ; teacher's role had an alpha of 0.37 ; audience alpha was 0.82 ; and technology alpha was 0.37 . The standard for instrument reliability for Cronbach's alpha by Robinson, Shaver, and Wrightsman (1991) was used to evaluate the quality of the scales of the attitude measures. These standards were: 0.80 or better - exemplary reliability; $0.70-$ 0.79 - extensive reliability; 0.60-0.69 - moderate reliability; and $<0.60$ - minimal reliability. Based on the above guidelines, the overall scale exhibited extensive reliability, and three subscales including 'motivation', 'group interaction', and 'audience' exhibited moderate reliability. Due to the low reliabilities of the teacher's role and technology scales, we deleted them from the analysis. Hence, only these three subscales were analysed in this study. Of the 59 students, 56 submitted questionnaires. Cases with missing data were excluded, such that the final sample size for data analysis was 51 ( $86 \%$ response).

The first author was a participant observer in the writing course to examine how primary students wrote compositions collaboratively on the JWC system, and to 
observe the group interactions during the collaborative writing process. She also helped students with technological problems during their writing process, and conducted the observations without a schedule, but took down descriptive field notes. The descriptive and narrative records were organised into categories to facilitate interpretations of the observed writing processes.

Semi-structured interviews with 14 students were conducted to help in understanding students' experiences and examining specific issues. Three randomly selected student groups and two randomly selected individual students were interviewed. Individual students were interviewed because one downside to focus group discussions is that some participants may be overly outspoken and overshadow quieter participants, and affect weak minded participants (Gay \& Airasian, 2003). The interview questions for focus groups and individual students were the same (Appendix B - translation by the author). Interviews were coded by the first author into themes, and each theme was given a label, the percentage of students who contributed to the theme was calculated, and representative statements for each were selected. Finally, the coded data were cross-checked by a research assistant to ensure the validity and reliability of data interpretation.

Quantitative data from the wiki documents for the two group composition assignments were collected. The researcher and the Chinese language teacher rated group compositions together, based on the elementary school high-grade narrative scoring criteria (Mo, 2010). The high-grade narrative scoring criteria is attached in Appendix C. The marks of the compositions were cross-checked by both the researcher and the Chinese language teacher, which resulted in $95 \%$ inter-rater agreement to ensure the inter-rater reliability of the composition scores.

\section{Results}

\section{How do students learn with the Wiki-based Collaborative Process Writing Pedagogy? What are the difficulties they encounter?}

This study lasted for around two months, and each group of students produced three compositions, one of which was used to train students to become familiar with the use of the wiki website and writing instructions, while the other two compositions (Table 2) were marked as assignments by the researcher and the Chinese language teacher. These two assignments were analysed in this study.

To help understand how students learned to write compositions collaboratively on the JWC system, what the classroom culture was like, and how students interacted with one another, the researcher attended classes as a participant observer.

During the writing process, students in each group wrote their compositions following the four stages (group prewriting, group drafting, revising and editing). According to the instructional design, each composition occupied two consecutive lessons and a certain amount of after-school time. The first lesson was conducted in the classroom, where the Chinese language teacher provided simple guidance for writing, and students of each group discussed their writing (group prewriting) content face to face. The second lesson was conducted in the computer lab, where students mainly did group drafting, revising and editing on the computers. The students continued to revise and edit their writing after school, until the deadline. 
Table 2: Topics of composition assignments

\begin{tabular}{|l|l|}
\hline $\begin{array}{c}\text { Number of } \\
\text { compositions }\end{array}$ & \multicolumn{1}{c|}{ Topics of compositions } \\
\hline Assignment 1 & $\begin{array}{l}\text { Please write down your feelings and experience on idyllic landscape. You can } \\
\text { write down what you want to write, which can be your own experience, what } \\
\text { you heard of, what you saw, or may be your imagination, or a feeling. You } \\
\text { should write clearly and pay attention to the accumulation of beautiful words } \\
\text { and sentences. Your article should not be less than 400 words. Please make sure } \\
\text { that each group completes the first draft in class. After class, please continue } \\
\text { modifying and editing your first draft, and finishing your second draft. The } \\
\text { deadline is 31 May. }\end{array}$ \\
\hline Assignment 2 & $\begin{array}{l}\text { Dear students, you are asked to write about "A person we respect." Around us, } \\
\text { there are many admirable people. The person may be your fellow student who } \\
\text { practises calligraphy diligently; or a cleaner working quietly in cold and hot } \\
\text { weather... choose one of them, through specific examples, praise their spirit of } \\
\text { persistence. If you think there are other characteristics that you admire, you can } \\
\text { also talk with us. Please state your feelings of admiration clearly. Your article } \\
\text { should not be less than 400 words. Please make sure that each group completes } \\
\text { the first draft in class. After class, please continue modifying and editing your } \\
\text { first draft, and finishing your second draft. Deadline for submission is at 12:00 } \\
\text { o'clock on 14 June. }\end{array}$ \\
\hline
\end{tabular}

During the writing process, both students and the teacher struggled with the collaborative aspects of the assignment. For the first composition assignment, two categories were derived from analysis of the data. The first one was peer negotiation. In the pre-writing stage, students in each group spent at least 5 minutes discussing their writing content and the roles and responsibilities of each member in the group. Usually, peer negotiation of divergent viewpoints slowed their process. The second category was editing clashes. In the following stages, students of the same group were required to write on their wiki page in parallel. However, the researcher observed popup message windows which showed "editing clash" when students wrote synchronously on the same wiki page. The edit clashes slowed the writing process, and only the writing of the student who wrote first was recorded on the wiki. In order to deal with the problem of editing clashes, for the second composition assignment, students in each group were asked to write their compositions in sequence on their wiki page.

Another two categories were derived from analysis of the data of the second composition. The first one was peer negotiation as in the first composition. The second one was division of labor and collaboration. Students of the same group chose to assign different paragraphs to different members, and the group leader wrote first on the wiki page for around 10 minutes. At the same time, other group members wrote on Microsoft Word and then transferred their writing to the wiki page when their turn came and continued to write for another 10 minutes until it was the time to pass the turn to another group member to use the wiki. In short, students of the same group wrote asynchronously and then modified and finished their composition collaboratively.

The researcher also identified three kinds of technical issues. The first kind concerned the mastery of MediaWiki's technical features. For example, there were students who did not know the function of historical record, and there were students who forgot 
their username or password, which seemed to exacerbate their frustration in using the wiki. The second kind of issue was about the knowledge of the formatting rules of MediaWiki. For instance, it was hard for primary students to upload a picture since students needed to have some knowledge of hypertext markup language (HTML) in terms of the formatting rules. However, it is too difficult for primary students to master HTML. Furthermore, some students encountered difficulties in recovering from errors and formatting their articles. The third kind of technical issue concerned incompatibilities between the Chinese writing format and the formatting rules of MediaWiki. According to the requirements of the Chinese writing format, students needed to leave two blank spaces at the beginning of every paragraph. However, when students left two blank spaces at the beginning of a paragraph on the wiki, the text in this paragraph was put into a box produced by MediaWiki software, in accordance with its formatting rules.

\section{What is the level of performance of the students' writing with WCPWP?}

Over the study, students' writing activities on wikis varied widely from group to group. Table 3 gives information about the two assignments per group collected from the wiki documents, including the number of participants, the number of words, the number of group members' revisions as shown in the historical record, and the composition scores. Students collaborated in fourteen groups of four, named Group A to Group N.

Table 3: Summary of students' editing activities on JWC

\begin{tabular}{|c|c|c|c|c|c|c|c|c|}
\cline { 2 - 9 } Group & \multicolumn{4}{|c|}{ Composition One } & \multicolumn{4}{c|}{ Composition Two } \\
\cline { 2 - 10 } & $\begin{array}{c}\text { No. } \\
\text { participants }\end{array}$ & $\begin{array}{c}\text { No. } \\
\text { words }\end{array}$ & $\begin{array}{c}\text { No. } \\
\text { revisions }\end{array}$ & $\begin{array}{c}\text { Group } \\
\text { score }\end{array}$ & $\begin{array}{c}\text { No. } \\
\text { participants }\end{array}$ & $\begin{array}{c}\text { No. } \\
\text { words }\end{array}$ & $\begin{array}{c}\text { No. } \\
\text { revisions }\end{array}$ & $\begin{array}{c}\text { Group } \\
\text { score }\end{array}$ \\
\hline A & 3 & 289 & 6 & 19 & 3 & $345^{*}$ & $10^{*}$ & $20^{*}$ \\
\hline B & 2 & 531 & 7 & 21 & 3 & $878^{*}$ & $18^{*}$ & 21 \\
\hline C & 4 & 773 & 8 & 18 & 3 & 323 & 8 & $19^{*}$ \\
\hline D & 2 & 516 & 5 & 26 & 2 & $590^{*}$ & 5 & $27^{*}$ \\
\hline E & 2 & 203 & 6 & 16 & 3 & 114 & 5 & 10 \\
\hline F & 0 & 30 & 1 & 0 & 1 & $161^{*}$ & $3^{*}$ & $8^{*}$ \\
\hline G & 1 & 143 & 1 & 14 & 4 & $501^{*}$ & $8^{*}$ & $24^{*}$ \\
\hline H & 2 & 0 & 0 & 0 & 3 & $122^{*}$ & $9^{*}$ & $11^{*}$ \\
\hline I & 1 & 29 & 1 & 3 & 2 & $144^{*}$ & $5^{*}$ & $10^{*}$ \\
\hline J & 2 & 830 & 1 & 26 & 1 & 467 & $5^{*}$ & 25 \\
\hline K & 3 & 845 & 8 & 19 & 4 & $229^{*}$ & $8^{*}$ & $12^{*}$ \\
\hline L & 2 & 38 & 1 & 3 & 2 & $443^{*}$ & 7 & $24^{*}$ \\
\hline M & 3 & 413 & 10 & 20 & 4 & $387^{*}$ & $10^{*}$ & $25^{*}$ \\
\hline N & 4 & 548 & 3 & 21 & 4 & $/ \mathrm{n}$ & $113^{*}$ & $259^{*}$ \\
\hline Total & 31 & $/ n$ & 58 & 206 & $39^{*}$ & 19 & $8^{*}$ \\
\hline
\end{tabular}

* Denotes that the score in Composition Two is higher than that in Composition One.

As shown in Table 3, more students participated in the second composition. The total number of students in the second composition was 39, which was 8 more than in the first writing (31). In the second composition, most groups $(71.4 \%)$ wrote more words, except Groups C, E, J and K. Ten groups made more revisions in Composition Two than in Composition One, and two groups (C, D) made the same number of changes; only Group E and Group M made fewer modifications in Composition Two than in Composition One. Overall, the total number of modifications for Composition Two was 113 compared to the total number of 58 for Composition One. Among the 14 
groups, 10 groups $(71.4 \%)$ achieved higher scores in Composition Two. The mean score for Composition Two was 3.79 marks higher (26\% increase) than that of Composition One, and a pair-sampled $t$-test indicated that the difference was significant at $\mathrm{p}<0.05$ (see Table 4).

Table 4: Paired samples test of students' compositions scores on JWC

\begin{tabular}{|c|c|c|c|c|c|c|c|c|}
\hline & \multicolumn{5}{|c|}{ Paired differences } & & \multirow{3}{*}{$\mathrm{df}$} & \multirow{3}{*}{$\begin{array}{c}\text { Sig. } \\
\text { (2-tailed) }\end{array}$} \\
\hline & \multirow[t]{2}{*}{ Mean } & \multirow[t]{2}{*}{$\begin{array}{l}\text { Std. } \\
\text { dev. }\end{array}$} & \multirow{2}{*}{$\begin{array}{l}\text { Std. error } \\
\text { mean }\end{array}$} & \multicolumn{2}{|c|}{$\begin{array}{l}95 \% \text { confidence } \\
\text { interval of the difference }\end{array}$} & & & \\
\hline & & & & Lower & Upper & & & \\
\hline Pair1: s1 - s2 & -3.79 & 5.37 & 1.43 & -6.88 & -0.69 & -2.64 & 13 & $0.02^{*}$ \\
\hline
\end{tabular}

Notes: $\mathrm{s} 1$ = score for Composition One; $\mathrm{s} 2$ = score for Composition Two; ${ }^{*} \mathrm{p}<0.05$. Score for

Composition Two was deducted from the score for Composition One.

The study opened wiki pages for parent groups, to encourage parents to put forward their comments and suggestions for their children. However, not a single parent wrote a word on the wiki during the duration of the study.

\section{What are the attitudes and perceptions of teacher and students towards WCPWP?}

The course feedback scale tested students' attitudes and perceptions toward WCPWP. Table 5 shows that the mean score of each item in the Motivation, Interaction, and Audience subscales was higher than 3 (Neutral $=3$ ), which reveals that students perceived collaborative writing using a wiki as beneficial in boosting their writing motivation, increasing group interactions, and extending the audience for their writings.

Table 6 shows the findings from interviews with students, which supplemented the course feedback questionnaire. Students' statements were initially examined to group similar comments into themes. The fit between each statement and the theme was evaluated. Finally, each theme was given a label, the percentage of students who contributed comments to the theme was calculated, and representative statements were selected (translations by the author).

According to Table 6, four positive themes emerged: learning benefits (93\% students), group interaction ( $86 \%$ students), technology advantages ( $86 \%$ students), and audience (71\% students). For instance, S1 and S2 were very happy with Wiki-based Collaborative Process Writing Pedagogy (WCPWP).

S1: I like writing on JWC, since I can communicate with other students more, and learn from their writing method [...] I have learned that we need a central sentence in every paragraph, and a link sentence between every two paragraphs, or two different points [...] I discussed with others better, and adopted the better opinion of others. I can get comments from others in order to improve my writing step by step [...] traditionally, teacher, parents, and a small amount of students were the audience of my composition. By using the wiki, there is a larger audience which increased my enthusiasm for writing...

S2: After writing on JWC, I feel writing is so enjoyable[...] When I write now, I can think more and deeper than in the past when I was taught by my teacher using the traditional writing approach. Now with JWC, I can discuss my ideas with my group members. I have learned a lot of new ideas from them... 
Table 5: Students' attitudes and perceptions toward the Wiki-based Collaborative Process Writing Pedagogy $(\mathrm{N}=51)$

\begin{tabular}{|c|c|c|c|c|}
\hline Subscale & Items & Mean & SD & $\begin{array}{l}\text { Cronbach's } \\
\text { alpha }\end{array}$ \\
\hline \multirow[t]{6}{*}{ 1. Motivation } & $\begin{array}{l}\text { 1. I like writing collaboratively on "Joyous Writing } \\
\text { Club". }\end{array}$ & 4.61 & 0.64 & \multirow[t]{6}{*}{$0.87^{\star *}$} \\
\hline & $\begin{array}{l}\text { 2. Compared with writing with pen and paper, I prefer } \\
\text { writing on "Joyous Writing Club" more. }\end{array}$ & 4.61 & 0.80 & \\
\hline & 3. "Joyous Writing Club" improved my writing interest & 4.49 & 0.86 & \\
\hline & $\begin{array}{l}\text { 4. I participated in writing more because of "Joyous } \\
\text { Writing Club". }\end{array}$ & 3.86 & 1.10 & \\
\hline & $\begin{array}{l}\text { 5. I continued to write more because of using "Joyous } \\
\text { Writing Club". }\end{array}$ & 4.00 & 1.08 & \\
\hline & $\begin{array}{l}\text { 6. I hope to continue using "Joyous Writing Club" next } \\
\text { semester. }\end{array}$ & 4.73 & 0.70 & \\
\hline \multirow[t]{6}{*}{$\begin{array}{l}\text { 2. Group } \\
\text { interaction }\end{array}$} & $\begin{array}{l}\text { 7. I learned a lot from my group members, which } \\
\text { enriched my writing content. }\end{array}$ & 4.61 & 0.67 & \multirow[t]{6}{*}{$0.63^{\star *}$} \\
\hline & $\begin{array}{l}\text { 8. On the whole, the conflict among group members } \\
\text { brought more benefits than disadvantages. }\end{array}$ & 3.84 & 1.30 & \\
\hline & $\begin{array}{l}\text { 9. I think the contribution of every member is } \\
\text { important. In order to write the best composition, } \\
\text { everyone needs to try his/ her best. }\end{array}$ & 4.76 & 0.55 & \\
\hline & $\begin{array}{l}\text { 10. I think that whether or not students collaborate } \\
\text { successfully in a group affects collaborative writing } \\
\text { significantly. }\end{array}$ & 4.33 & 1.07 & \\
\hline & $\begin{array}{l}\text { 11. I think interaction among students can improve my } \\
\text { writing ability more than only interaction with the } \\
\text { teacher. }\end{array}$ & 4.61 & 0.90 & \\
\hline & $\begin{array}{l}\text { 12. Compared with the traditional writing, interaction } \\
\text { on "Joyous Writing Club" improved my writing ability. }\end{array}$ & 4.65 & 0.66 & \\
\hline \multirow[t]{2}{*}{ 4. Audience } & $\begin{array}{l}\text { 16. Since more people can know our compositions, I } \\
\text { have become more active in writing. }\end{array}$ & 4.47 & 0.86 & \multirow[t]{2}{*}{$.82^{\star *}$} \\
\hline & $\begin{array}{l}\text { 17. I think there is a larger audience when we write on } \\
\text { "Joyous Writing Club", which is one advantage of this } \\
\text { writing environment. }\end{array}$ & 4.31 & 0.97 & \\
\hline
\end{tabular}

** The standards for Cronbach alpha reliability value for evaluating attitude measures were: 0.80 or better - exemplary reliability; 0.70-0.79 - extensive reliability; 0.60-0.69 - moderate reliability; and < 0.60 - minimal reliability (Robinson et al., 1991, p. 13)

Students also put forward three negative themes: collaboration problem (100\%), time issue (57\% students), and technology disadvantages (71\% students) (see Table 6).

S3: Sometimes, we had different opinions; some members argued and insisted on their opinions [...] We also encountered technology problems in the classroom, for example, we failed to save the writing on the wiki, and it is very slow for us to open or save the wiki page sometimes, and usually we cannot finish our writing in class [...] Some bad students destroyed our writing on our page on purpose, and our article was lost suddenly...

Students also expressed their perceptions of the teacher's role (43\% students), and indicated that the writing topics (36\%) (see Table 6) may affect the collaborative writing result, since some writing topics are not suitable for using WCPWP. 
S1: I think teacher's guidance is not important during the collaborative writing process. The most important is students' collaborative writing process and their writing attitudes.

S4: Some topics are easy for the group to write together, but some are hard. It depends on the topic of the composition. For example, the composition, "a person I respect" was hard for us to write collaboratively since we respect different persons; we need to write about a person we all know and respect; it is hard.

Table 6: Interview findings ( $\mathrm{N}=14$ students)

\begin{tabular}{|c|c|c|c|c|}
\hline \multicolumn{2}{|r|}{ Themes } & $\mathrm{n}$ & $\%$ & Representative views \\
\hline \multirow[t]{4}{*}{ Positive } & $\begin{array}{l}\text { Learning } \\
\text { benefits }\end{array}$ & 13 & $93 \%$ & $\begin{array}{l}\text { Improved their writing ability, writing interest, computer } \\
\text { skills, and collaborative ability. }\end{array}$ \\
\hline & $\begin{array}{l}\text { Group } \\
\text { interaction }\end{array}$ & 12 & $86 \%$ & Wiki facilitated collaborative learning within a group. \\
\hline & $\begin{array}{l}\text { Technology } \\
\text { advantages }\end{array}$ & 12 & $86 \%$ & $\begin{array}{l}\text { Students could write at anytime in and after class; it was } \\
\text { easier for peer edits, revision and comments. }\end{array}$ \\
\hline & Audience & 10 & $71 \%$ & $\begin{array}{l}\text { A larger audiences motivated their writing; at the same } \\
\text { time, as the audience themselves, they learned from one } \\
\text { another's compositions. }\end{array}$ \\
\hline \multirow[t]{3}{*}{ Negative } & $\begin{array}{l}\text { Collaboration } \\
\text { problems }\end{array}$ & 14 & $100 \%$ & $\begin{array}{l}\text { They usually had different opinions of the writing content. } \\
\text { Some members did not write, or wrote very few words. }\end{array}$ \\
\hline & Time issue & 8 & $57 \%$ & $\begin{array}{l}\text { One lesson time in computer lab was not enough, and it } \\
\text { was difficult for them to manage to write well after class }\end{array}$ \\
\hline & $\begin{array}{l}\text { Technology } \\
\text { disadvantages }\end{array}$ & 10 & $71 \%$ & $\begin{array}{l}\text { Some bad/naughty students in other groups went to their } \\
\text { writing place and changed their writing contents on } \\
\text { purpose. }\end{array}$ \\
\hline \multirow[t]{2}{*}{ Other } & Teacher's role & 6 & $43 \%$ & $\begin{array}{l}\text { Teacher's guidance in writing was not important; they } \\
\text { needed the teacher to provide them with technology } \\
\text { support. }\end{array}$ \\
\hline & Writing topics & 5 & $36 \%$ & $\begin{array}{l}\text { Some writing topics are not good for writing } \\
\text { collaboratively, such as the topic of "A person I respect". }\end{array}$ \\
\hline
\end{tabular}

Analysis of the responses to the teacher's questionnaire after the experimental teaching indicates that the participating Chinese language teacher became more interested in using the collaborative writing method with the wiki, compared to the traditional individual writing method. She also expressed that, during the collaborative writing class with the wiki, her role was more that of a facilitator than an instructor.

Teacher: Students were interested in writing collaboratively in groups [...] I hope they can advance their writing ability, modification ability, and enhance their sense of teamwork from this collaborative writing activity... [...] I acted as a facilitator rather than an instructor...

\section{Discussion}

This study explored how a Wiki-based Collaborative Process Writing Pedagogy (WCPWP) was designed and implemented to facilitate Chinese writing among a class of primary four students in China. In doing so, this study designed a WCPWP based on social constructivist theory and social view of writing process theory, and investigated students' collaborative writing processes using WCPWP, students' online performance using WCPWP, and teacher and students' attitudes and perceptions towards WCPWP.

The results provided a general picture of students' collaborative writing processes using WCPWP. The researcher observed that students wrote their compositions on a 
wiki following the given cyclical and nonlinear writing process (group prewriting, group drafting, revising and editing) which supported the social view of writing process theory. During the writing process, students in each group communicated and interacted with each other, which was in line with the theoretical propositions of social constructivism (Cheng, 2009) that emphasise the collaborative nature of knowledge construction in group learning in a socio-cultural context (Vygotsky, 1978). The teacher indicated that factors such as writing topic and students' computer skills might affect the quality of collaborative writing with the wiki. During the students' writing, she became a facilitator rather than an instructor. Just as social constructivist theory explains, in student-centred learning activity, the role of the teacher is that of a facilitator, providing a framework (i.e. activities for students to complete) that facilitates student learning (Hiltz, 1994).

By analysing the results of the three research questions, this study generalised several specific themes regarding using WCPWP in Chinese writing among Chinese primary school students. The first theme is learning benefits. Students perceived WCPWP to be beneficial in boosting writing motivation, improving writing ability, computer skills, and collaborative ability. Most groups performed better in their second compositions (Table 3). It appears that a well-organised WCPWP could be used effectively and meaningfully in Chinese writing classes in primary school.

The second theme is group interaction or collaboration. Most students perceived WCPWP to be beneficial in increasing group interactions, which enriched their knowledge and improved their writing ability. Few students expressed that peer negotiation of inconsistent opinions and edit conflicts slowed down their writing process. The observed disadvantages of group interaction were consistent with Forte's (2009) findings from his study of a teacher-designed MediaWiki assignment in the Biogeochemical Cycles Project with undergraduate students. However, most students still expressed that conflicts among group members brought more benefits than disadvantages (Table 5). For instance, they can think more and deeper when discussing their ideas with their group members (S2), and also learned new ideas from their group members (S1 \& S2). In doing so, the opportunity for differing opinions in group discussions and arguments is enhanced, and these differences may provoke conceptual change (O'Donnell, 2006), subsequently, helping to co-construct students' new understanding and increase their knowledge (Pifarré \& Staarman, 2011).

The third theme is technical advantages and disadvantages associated with using WCPWP in Chinese writing. In terms of the technical advantages, students expressed that they could write at anytime in and after class; and it was easier for peer edits, revision and comments (Table 5). In the stages of group drafting, revising and editing, the function of open editing of the wiki, which allows participants add and delete the contents collaboratively (Pifarre \& Staarman, 2011), played an important role. Other studies have indicated wikis as valuable resources for revision and collaboration (Cress \& Kimmerle, 2008; Snodgrass, 2011). However, the researcher also observed three categories of technical disadvantages: first, some students did not master MediaWiki's technical features; second, it was difficult for upper primary students to have sufficient knowledge about MediaWiki's formatting rules; third, incompatibilities between Chinese writing formats and the formatting rules of MediaWiki. These problems could be alleviated or solved if some Chinese wiki projects with powerful functions and friendlier interfaces like PBworks.com or Wikispaces could be designed and developed for Chinese educational institutions. Currently, wiki systems like PBworks.com cannot be used in China; hence, this study was necessarily limited to the use of MediaWiki. 
Furthermore, student interviews showed another positive theme -- the audience for their writing was extended; and one negative theme which is that writing time in class was too limited for them to finish during class time. The findings are similar to Coley's (2007) study, indicating that the wiki could be used to facilitate collaboration and extend the audience in the writing class. In this study, students also expressed their perceptions of the teacher's role, which changed from that of an instructor to that of a facilitator, and indicated that not all writing topics were suitable for writing collaboratively.

\section{Conclusion}

To summarise, Wiki-based Collaborative Process Writing Pedagogy (WCPWP) focuses on a student-centred collaborative writing process, and is underpinned by the social constructivist paradigm and social view of writing process theory. After two months of implementation, teacher and students' attitudes and perceptions towards WCPWP were found to be positive, and students showed progress in their final composition on the wiki. The overall results suggest that a well-orchestrated WCPWP could be implemented effectively and meaningfully to support students' Chinese writing in primary school.

This case study has two limitations. The first is the low reliability of the two subscales teacher's role and wiki technology, which may be improved with a larger sample size. The second comes from the computer equipment and the network speed in the participating school. Perhaps, better facilities may address some of the problems encountered by the students. Further studies are still needed to improve and refine WCPWP, as well as exploring the effect of WCPWP on students' writing ability.

This study has important implications. In terms of theoretical significance, it shows that Chinese students can use wikis effectively in a collaborative Chinese writing context. This extends previous literatures which have focused mostly on Englishspeaking participants (Mak \& Coniam, 2008; Wong, Chen, Chai, Chin \& Gao, 2011; Woo, Chu, Ho \& Li, 2009, 2011). This study also has practical implications. It may help primary educators gain a deeper understanding of the relationships between technology, pedagogy and education. It may also provide practical guidelines for educators in the integration of Web 2.0 tools (wikis, Google Docs) as well as the use of effective pedagogical strategies in the teaching of Chinese writing in China.

\section{Acknowledgment}

The authors wish to thank Dr Jan van Aalst, of the Faculty of Education, HKU, for his valuable comments in the manuscript preparation.

\section{References}

Almala, A. H. (2006). Applying the principles of constructivism to a quality e-learning environment. Distance Learning, 3(1), 33-41. http:/ / www.highbeam.com/ doc/1P31269826961.html

Bogdan, R. C. \& Biklen, S. K. (2006). Qualitative research for education: An introduction to theories and methods (5th ed.). Boston: Pearson Education Group.

Bower, M. (2008). Affordance analysis - matching learning tasks with learning technologies. Educational Media International, 45(1), 3-15. http: / / dx.doi.org/10.1080/09523980701847115 
Cheng, G. (2009). Using game making pedagogy to facilitate student learning of interactive multimedia. Australasian Journal of Educational Technology, 25(2), 204-220.

http:// www.ascilite.org.au/ajet/ajet25/cheng.html

Choy, S. O. \& Ng, K. C. (2007). Implementing wiki software for supplementing online learning. Australasian Journal of Educational Technology, 23(2), 209-226. http: / / www.ascilite.org.au/ajet/ajet23/ choy.html

Ciesielka, D. (2008). Using a wiki to meet graduate nursing education competencies in collaboration and community health. Journal of Nursing Education, 47(10), 473-476. http: / / www.slackjournals.com/article.aspx?rid=34249

Clark, I. L. (2003). Concepts in composition theory and practice in the teaching of writing. London: Lawrence Erlbaum Associates.

Coley, T. F. (2007). Wikis in the teaching of writing: Purposes for implementation. Unpublished M.A. Thesis. North Carolina State University. http: / / www.lib.ncsu.edu/ resolver/1840.16/2803

Cress, U. \& Kimmerle, J. (2008). A systemic and cognitive view on collaborative knowledge building with wikis. International Journal of Computer-Supported Collaborative Learning, 3(2), 105-122. http: / / dx.doi.org/10.1007/ s11412-007-9035-z

Cui, L. (2007). On the Chinese language textbook compiling for elementary schools in China. In Z. Hong, S. Liu \& W. Ni (Eds.), A study of first language textbooks (Vol. 9, pp. 170-204). Nanjing: Jiangsu Education Publishing House.

Denzin, N. K. (Ed.). (1989). The research act: A theoretical introduction to sociological methods (3rd ed.). Englewood Cliffs, N.J.: Prentice Hall.

Faigley, L. (1986). Competing theories of process: A critique and a proposal. College English, 48(6), 527-542. http: / / www.jstor.org/pss/376707

Forte, A. (2009). Learning in public: Information literacy and participatory media. Unpublished thesis for Doctor of Philosophy. School of Interactive Computing, College of Computing, Georgia Institute of Technology. http:/ / hdl.handle.net/1853/29767

Gage, N. (1986). Why write? In A. N. Petrovsky \& D. Bartholomae (Eds.), The teaching of writing. (Eighty-fifth yearbook of the National Society for the Study of Education). Chicago: University of Chicago Press.

Gay, L. R. \& Airasian, P. (2003). Educational research: Competencies for analysis and application (7th ed.). Upper Saddle River, NJ: Merrill.

$\mathrm{Gu}, \mathrm{K}$. (2004). Investigating the process-oriented writing approach. Journal of Anhui University (Philosophy and Social Sciences), 28(6).

Hazari, S., North, A. \& Moreland, D. (2009). Investigating pedagogical value of wiki technology. Journal of Information Systems Education, 20(2), 187-198. [abstract only] http: / /jise.org/Volume20/20-2/Pdf/V20N2P187-abs.pdf

Hewett, B. L. (2009). Generating new theory for online writing instruction. Kairos, 6(2). [viewed 10 Dec 2009, verified 24 Jan 2012] http: / / english.ttu.edu/kairos/6.2/ features / hewett /

Hidi, S. \& Harackiewicz, J. M. (2000). Motivating the academically unmotivated: A critical issue for the 21st century. Review of Educational Research, 70(2), 151-179. http: / / dx.doi.org/10.3102/00346543070002151

Hiltz, S. R. (1994). The virtual classroom: Learning without limits via computer networks. Norwood, NJ: Ablex. 
Huang, Z. (2008). Calling for ture emotions in primary school students' Chinese writing. Education of Science, 11, 43. [citation correction in progress]

Lam, W.-S. (2007). An action research project to explore the effects of collaborative learning on students' writing quality and their conceptions of writing. Unpublished Thesis for Master of Arts in Applied Linguistics, University of Hong Kong, Hong Kong.

Lamb, A. \& Johnson, L. (2007). An information skills workout: Wikis and collaborative writing. Teacher Librarian, 34(5), 57-59. http: / / www.highbeam.com/ doc/1G1-164424176.html

Lamb, B. (2004). Wide open spaces: Wikis, ready or not. EDUCAUSE Review, 39(5), 36-48. http: / / www.educause.edu/EDUCAUSE+Review / EDUCAUSEReviewMagazineVolume39/ WideOpenSpacesWikisReadyorNot/157925

Liang, S.-T. (1995). Effects of online peer assessment upon the sixth-graders' learning of writing. Unpublished Masters Thesis, National Central University, Taipei.

http: / / thesis.lib.ncu.edu.tw / ETD-db / ETD-search / view_etd?URN=92127006

Liu, Z. (2009). Teaching and Learning of primary Chinese writing under the background of Chinese new curriculum. New Curriculum Research, 2(140), 123.

Ma, Q. (2009). Discussing about the inquiring teaching method in primary school students' Chinese writing. New Curriculum Research, 2(140), 49-50.

Mak, B. \& Coniam, D. (2008). Using wikis to enhance and develop writing skills among secondary school students in Hong Kong. System, 36, 437-455. http: / / dx.doi.org/10.1016/j.system.2008.02.004

Mo, D. (2010). Primary school Chinese essay scoring criteria. [viewed Mar 2010, verified 24 Jan 2012; in Chinese] http:/ / blog.163.com/keke_0912/blog/static/6067032120081126102826181/

New Criteria of Chinese Curriculum (2003). The national curriculum criteria album - criteria of Chinese course. [in Chinese] http: / / www.being.org.cn/ncs/chn/chn.htm

O'Donnell, A. M. (2006). Introduction: Learning with technology. In A. M. O'Donnell, C. E. Hmelo-Silver \& G. Erkens (Eds.), Collaborative learning, reasoning, and technology (pp. 1-13). Mahwah, New Jersey: Lawrence Erlbaum Associates.

PBworks (2010). http:/ / pbworks.com/content/about

Pifarré, M. \& Staarman, J. K. (2011). Wiki-supported collaborative learning in primary education: How a dialogic space is created for thinking together. International Journal of ComputerSupported Collaborative Learning, 6(2), 187-205. http: / / dx.doi.org/10.1007/ s11412-011-9116-x

Reeves, J. (2002). Writing alone, writing together: A guide for writers and writing groups. Novato, California: New World Library.

Rick, J. \& Guzdial, M. (2006). Situating CoWeb: A scholarship of application. International Journal of Computer-Supported Collaborative Learning, 1(1), 89-115. http:/ / dx.doi.org/10.1007/s11412006-6842-6

Robinson, J. P., Shaver, P. R. \& Wrightsman, L. S. (1991). Measures of personality and social psychological attitudes. San Diego, California: Academic Press.

Snodgrass, S. (2011). Wiki activities in blended learning for health professional students: Enhancing critical thinking and clinical reasoning skills. Australasian Journal of Educational Technology, 27(4), 563-580. http: / / www.ascilite.org.au/ajet/ajet27/snodgrass.html 
Sun, Q. (2008). My opinion towards Chinese writing in primary school. Journal of Educational Institute of Jilin Province, 24(198), 152.

Timina, S. A. (2010). On the interference of Chinese in using English as a foreign language. [verified 24 Jan 2012] http:/ / de.dstu.edu.ru/CDOSite/ConfEng/articles\%5Carticle23.htm

Tobin, L. (2001). Process pedagogy. In G. Tate, A. Rupiper \& K. Schick (Eds.), A guide to composition pedagogies (pp. 1-18). New York Oxford: Oxford University Press.

Tompkins, G. E. (2008). Literacy for the 21st Century: A balanced approach, 5th Edition. Boston: Allyn \& Bacon.

Vygotsky, L. S. (1978). Mind in society: The development of higher psychological processes. Cambridge, MA: Harvard University Press.

Wang, D. (2004). Between the ideal and realistic - On the state of two kinds writing. Chinese Language Learning, 2004(2).

Wang, M., Perfetti, C. A. \& Liu, Y. (2004). Chinese-English biliteracy acquisition: Cross-language and writing system transfer. Cognition, 97(1), 67-88. http:/ / dx.doi.org/10.1016/j.cognition.2004.10.001

Wang, X. Q. (2008). Preliminary study on the method of training students' writing skills. Ke Jiao Wen Hui, 7(Mid), 96.

Wetpaint (2010). http: / / www.wetpaint.com/page/ About

Wikia (2010). http: / / www.wikia.com/Wikia

Wikispaces (2010). http: / / www.wikispaces.com/

Witts, J. (2011). The educational value of Web 2.0 technologies in a social constructivist and situative learning theory. [viewed 30 Dec 2011, verified 24 jan 2012] http:/ / www.jonwitts.co.uk/elearning/web2/web_2_essay.pdf

Wong, L.-H., Chen, W., Chai, C.-S., Chin, C.-K., \& Gao, P. (2011). A blended collaborative writing approach for Chinese L2 primary school students. Australasian Journal of Educational Technology, 27(7), 1208-1226. http: / / www.ascilite.org.au/ajet/ajet27/wong-lh.html

Woo, M., Chu, S. K. W., Ho, A. \& Li, X. (2009). Collaborative writing with a wiki in a primary five English classroom. Paper presented at the The 6th International Conference on Knowledge Management. http:/ / eproceedings.worldscinet.com/9789814299862/9789814299862_0016.html

Woo, M., Chu, S. K. W., Ho, A., \& Li, X. (2011). Using a wiki to scaffold primary school students' collaborative writing. Educational Technology E Society, 14(1), 43-54. http:// www.ifets.info/journals/14_1/5.pdf

Wu, Z. (2009). Thinking about teaching and innovation of Chinese writing in middle school in the Internet age. View New Observations of Education, 3, 5-6.

Xie, T. (2006). Blog, wiki, podcasting and learning chinese language. Paper presented at the The 5th International Conference on New Technologies in Teaching and Learning Chinese. [in Chinese] http: / / www.csulb.edu / txie / papers / Blog\%20Wiki\%20Pod $\% 20$ Can $\% 20 w e \% 20$ use $\% 20$ them $\% 20$ full $\% 20$ text.pdf

Xiong, X. (1995). Teaching and learning of Chinese writing in the twenty-first century. Journal of Jinzhu University, 3(19), 45-47.

Xia, B. (2009). Enlightment that constructivist learning theory gave to teaching and learning of Chinese writing in middle school. Journal of Mudanjiang College of Education, 1, 133-134. 
Xu, P. \& Jen, T. (2005). "Penless" Chinese language learning: A computer-assisted approach. Journal of Chinese Language Teachers Association, 40(2), 25-42.

Zhu, G. X. (2010). Discussion about the teaching of writing under the new curriculum reform. New Curriculum, 28 December, 177-178.

\section{Appendix A: Questionnaire for teachers}

Please finish the questionnaire within 20 minutes. We will keep all the information you provide to us completely confidential. Thanks.

Name: Gender:

Age:

1. What challenges and issues did you face when using a wiki to orchestrate the collaborative writing activities in your class?

2. How did you deal with the challenges and issues encountered?

3. From your observation, what is / are students' response(s) regarding group writing using a wiki?

a. Compared to their traditional individual writing, do these students become more interested in their writing when doing it using a wiki?

b. What kinds of difficulties did your students encounter in using a wiki for their writing?

c. How did the students manage to overcome them? And what kind of assistance did you offer to them?

4. What observable improvement in writing ability, if any, did you see in the students' work compared to their previous writing without using a wiki?

5. How does wiki's tracking system help you provide support during the editing process in collaborative writing? What kind of support did you provide?

6. How would you define your role regarding the whole process of students' collaborative writing?

7. Did your students show improvement in other abilities other than their writing ability? For example, reading ability, IT ability, knowledge management, collaboration ability, etc.?

8. From your perspective, what are your perceived benefits gained by the students through this mode of learning using a wiki?

9. Will you continue to use the wiki-based collaborative process writing pedagogy in the future? Why?

10. Any other comments?

\section{Appendix B: Semi-structured interview questions to students}

1. Compared with writing with paper and pencil, do you like writing in "joyous writing club" more? Why?

2. Do you think you can learn a lot from your peers in the collaborative writing process? What have you learned?

3. Do you think the different opinions of your group members will affect the writing result? Why?

4. Do you think you still want to write Chinese collaboratively next semester?

5. Do you think the collaborative writing approach can help you improve your writing better, compared with a traditional writing approach?

6. Do you think teacher's guidance is very important in the collaborative writing process? What other help do you need from the teacher?

7. Since you can receive evaluation and comments from your group members when you write collaboratively with the wiki, do you think it is better than only receiving comments from your Chinese teacher?

8. Since there is a larger audience who can view your article when you write composition on the wiki, do you think this is an advantage of using wiki that can help you write composition more efficiently? 
9. When you write a composition on the wiki, do you think the communication among your classmates is very helpful for your writing?

10. Do you think the writing activities and the writing ability of each group member in your group will affect the writing result significantly?

11. Do you think the instructional design will affect the writing result significantly? For instance, how to group students? How will group members collaborate with each other?

12. What advantages does wiki-based collaborative process writing pedagogy have in your experience?

13. What disadvantages does wiki-based collaborative process writing pedagogy have in your experience?

\section{Appendix C: Elementary school high-grade narrative scoring criteria}

Proportion of components: (full score is 30 points)

1. Topic $-5 \%, 1.5$ points.

2. Ideas $-25 \%, 7.5$ points.

3. Content $-30 \%, 9$ points.

4. Organisation $-10 \%, 3$ points.

5. Sentence fluency $-20 \%, 6$ points.

6. Punctuation and spelling - $10 \%, 3$ points; one incorrect character/punctuation is 0.5 points.

First Level Standard: (27-30 points)

1. Topic: The topic of the composition is appropriate.

2. Ideas: The writing ideas are healthy, clear and focused with a central theme completely.

3. Content: Details support the theme. The description is vivid and the content can capture the readers' interests. Besides, the content has intrinsic value.

4. Organisation: Information is presented in clear sequence, making connections and transitions among sentences and paragraphs.

5. Sentence fluency: The writer develops smooth flow and rhythm in sentences. Text has a natural, fluent sound; with a combination of simple, compound, and complex sentences beginning in a variety of ways throughout the text; with good use of Chinese idioms, rhetoric, and proverbs.

6. Punctuation and spelling: The writer uses correct punctuation, capitalisation and grammar. The writer uses correct spelling. The composition has enough characters.

Second Level Standard: (24-26 points)

1. Topic: The topic of the composition is appropriate

2. Ideas: Addresses the prompt with a single incident/experience.

3. Content: Most effective details can show the reader about the event. Includes a slowed down step-by-step elaboration.

4. Organisation: Have obvious beginning, middle, and end. Closing of at least two sentences that express an observation, reaction or feeling.

5. Sentence fluency: Extensive variation in sentence structure, length, and beginnings that flow easily. Have used some Chinese idioms, rhetoric, and proverbs.

6. Punctuation and spelling: Most punctuation, capitalisation and grammar are correct. All high frequency characters spelled correctly, all incorrectly spelled characters are easily decipherable.

Third Level Standard: (18-23 points)

1. Topic: The topic of the composition is appropriate.

2. Ideas: Focuses on a single incident or experience.

3. Content: Some sensory details and/or feelings tell the reader about the event.

4. Organisation: Organisation demonstrates sequencing of related ideas.

5. Sentence fluency: Good control over simple sentences and uses compound and complex sentences.

6. Punctuation and spelling: High frequency characters, punctuation, capitalisation and grammar are correctly used, one or more of incorrectly spelled characters not easily decipherable. 
Fourth Level Standard: (12-17 points)

1. Topic: The topic of the composition is appropriate

2. Ideas: Attempts to group related ideas.

3. Content: Few sensory details and/or feelings tell the reader about the event.

4. Organisation: Shows an attempt to sequence. Obvious transitions. Have one to two paragraphs.

5. Sentence fluency: Good control over simple sentences. Some variety in sentence structure, length, and beginning.

6. Punctuation and spelling: Certain number of characters, punctuation, capitalisation and grammar are incorrectly used, one or more of incorrectly spelled characters not easily decipherable.

Fifth Level Standard: (0-11 points)

1. Topic: The topic of the composition is inappropriate

2. Ideas: Lacks a central idea or purpose.

3. Content: Text is difficult to understand.

4. Organisation: Random sentences. Writing unclear with redundant/obvious transitions

5. Sentence fluency: Writing is difficult to follow or read.

6. Punctuation and spelling: High frequency characters may be spelled incorrectly, one or more of incorrectly spelled characters not easily decipherable. Less than 300 characters.

Authors: Miss Li Xuanxi, PhD Candidate

HOC 109, Faculty of Education, The University of Hong Kong

Email: xuanxi6@hku.hk

Dr Samuel K. W. Chu, Associate Professor

Faculty of Education, The University of Hong Kong

Email: samchu@hkucc.hku.hk

Dr Wing Wah Ki, Associate Professor

Faculty of Education, The University of Hong Kong

Email: hraskww@hkucc.hku.hk

Matsuko Mukumoto Woo, EdD Candidate

Faculty of Education, The University of Hong Kong

Email:matsuko@netvigator.com

Please cite as: Li, X., Chu, K. W., Ki, W. W. \& Woo, M. M. (2012). Using a wiki-based collaborative process writing pedagogy to facilitate collaborative writing among Chinese primary school students. Australasian Journal of Educational Technology, 28(1), 159-181. http:/ / www.ascilite.org.au/ajet/ajet28/li.html 